\title{
Author Correction: First-hand, immersive full-body experiences with living cells through interactive museum exhibits
}

Amy T. Lam, Joyce Ma, Cory Barr, Seung Ah Lee, Adam K. White, Kristina Yu and Ingmar H. Riedel-Kruse

Correction to: Nature Biotechnology https://doi.org/10.1038/s41587-019-0272-2, published online 2 October 2019.

In the version of this article initially published, an affiliation was omitted for author Seung Ah Lee: School of Electrical and Electronic Engineering, Yonsei University, Seoul, Republic of Korea. The error has been corrected in the HTML and PDF versions of the article.

Published online: 24 October 2019

https://doi.org/10.1038/s41587-019-0320-y

() Springer Nature America, Inc. 2019

\section{Author Correction: Shadow pricing and the art of profiteering from outdated therapies}

Anurag S. Rathore (D) and Faheem Shereef

Correction to: Nature Biotechnology https://doi.org/10.1038/s41587-019-0049-7, published online 26 February 2019.

In the version of this article initially published, the second author's last name was given as Shaheef; the correct name is Shereef. The error has been corrected in the HTML and PDF versions of the article.

Published online: 1 November 2019

https://doi.org/10.1038/s41587-019-0317-6

๑ Springer Nature America, Inc. 2019

\section{Author Correction: The influence of domestic manufacturing capabilities on biologic pricing in emerging economies}

Anurag S. Rathore (D) and Faheem Shereef

Correction to: Nature Biotechnology https://doi.org/10.1038/s41587-019-0116-0, published online 3 May 2019.

In the version of this article initially published, the second author's last name was given as Shareef; the correct name is Shereef. The error has been corrected in the HTML and PDF versions of the article.

Published online: 1 November 2019

https://doi.org/10.1038/s41587-019-0318-5

(c) Springer Nature America, Inc. 2019 